九州大学学術情報リポジトリ

Kyushu University Institutional Repository

\title{
Further Data On The Crossing Of Albino Ring Doves With White Ones
}

Tange, Masaharu

Laboratory of Zootechny, Faculty of Agriculture, Kyushu University

https://doi.org/10.5109/22617

出版情報 : 九州大学大学院農学研究院紀要. 9 (2)，pp.127-142，1949-05. Kyushu University バージョン：

権利関係 : 


\title{
FURTHER DATA ON THE CROSSING OF ALBINO RING DOVES WITH WHITE ONES*
}

\author{
Masaharu Tange
}

\section{INTRODUCTION}

In the previous paper on the studies of the sex-linked in heritance of plumage color in the ring dove, the writer (Tange, 1934) reported the results of crossing albino ring doves (which had mutated to blond ones in his aviary and were named by him "Albino I") with white ones. This cross breeding produced colored or blond individuals in $F_{1}$; that is, blond females and blond males in equal number from the crossing of a white female with an albino male, and white females and blond males in equal number from the crossing of an albino female with a white male. The results from these studies in addition to those obtained by crossing blond ring doves with white ones, so far as the plumage color was concerned, may be designated by the following genetic formulae:

Blond ring doves: $\quad+=\mathrm{CCZ}^{\mathrm{I} W}, \quad s=\mathrm{CCZ}^{1} \mathrm{Z}^{\mathrm{I}}$;

White ring doves: $q=\mathrm{CCZ} W, \quad b=\mathrm{CCZ}^{\mathrm{i}} \mathrm{W}$;

Albino ring doves: $\phi=c c Z^{\mathrm{I}} \mathrm{W}, \quad \partial=\mathrm{ccZ} Z^{\mathrm{I}}$.

He also considered another kind of albino ring doves, which he named "Albino II", of the genetic formulae, $\$=\operatorname{ccZ} \mathrm{W}$ and $\delta=c^{\prime} Z^{\prime} Z^{\prime}$, that was expected to be bred. The data presented

\footnotetext{
* The work was aided by the expenditure for scientific research from the Department of Education to the Laboratory for the Studies on the Genetics in Domestie. Animals. Part of the experimental results was reported before the Annual Grand Meeting of the Scientific Agricultural Society held in Tokyo. 1941.
} 
here are those of $\mathrm{F}_{2}$ 's obtained by crossing the albino ring doves ("Albino I") with white ones, as well as those obtained by cross. ing individuals which were mainly raised out of the offspring of albino ring doves crossed with white ones.

\section{Material aind Metroos}

The birds used here are the white and albino ring doves above-named and the cross-bred ones obtained by crossing albino ring doves with white ones. All of them were reared in the writer's aviary, and the pedigrees are known in full.

The methods of keeping birds, rearing squabs, and discriminat ing individuals are the same as described in the previous paper published in 1934 .

\section{EXPERIMENTAL RESULTS}

Some of the data concerning $F_{1}$ were presented. in the previous paper: when an albino male was crossed with a white female the sons and daughters were all blond, while in the reciprocal cross, i.e., a white male crossed with an albino female produced blond sons and white daughters. Further data concerning $F_{1}$, which have been obtained by continued crossing experiments show the same results, and are presented here in addition to the data con. cerning $\mathrm{F}_{2}$ and others.

$$
\text { (A) White } q \times \text { Albino } 8
$$

(a) $\mathrm{F}_{1}$

Table 1.

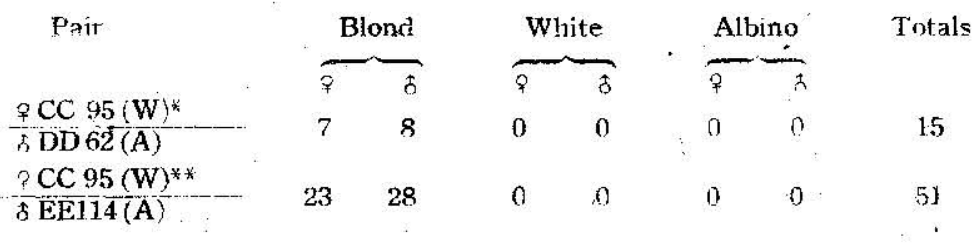

* The same pair and number of offspring as described in the previnus paper (Tange, 1934).

**The same pair as described in the previous paper, but the number of offspring increased.

$\mathrm{W}=$ =white, $\mathrm{A}=$ =albino, H.W = hybrid white. $\mathrm{H} . \mathrm{B}=$ hybrid blond. 


\begin{tabular}{|c|c|c|c|c|c|c|c|}
\hline$\frac{\text { \& BB5 (W) }}{3 \mathrm{EE} 118(\mathrm{~A})}$ & 20 & 19 & 0 & 0 & $u$ & 0 & 39 \\
\hline$\frac{7 \mathrm{CC} 185(\mathrm{H} \cdot \mathrm{W})^{*}}{\mathrm{EE} 32(\mathrm{~A})^{*}}$ & 1 & 3 & 0 & 0 & 0 & 0 & 4 \\
\hline$\frac{\psi \mathrm{HBB} 65(\mathrm{H} . \mathrm{W})}{\delta \mathrm{EE} \mathrm{32(A)}}$ & $y$ & 14 & 0 & $u$ & 0 & $v$ & 23 \\
\hline$\frac{f \operatorname{CC} 56(\mathrm{H} . W)}{\partial \mathrm{EE} 32(\mathrm{~A})}$ & 7 & 5 & 0 & $u$ & 0 & 0 & $1:$ \\
\hline$\frac{\mathrm{CC} 56(\mathrm{H} . \mathrm{W})}{3 \mathrm{GC} 7(\mathrm{~A})}$ & 48 & 44 & 0 & 0 & 0 & 6 & 2 \\
\hline Totąls & 115 & 121 & u & 0 & 0 & 0 & 236 \\
\hline Fxpected & 118.0 & 118.0 & 0 & 0 & 0 & 0 & 236 \\
\hline Standard error & \pm 7.6 & \pm 7.68 & & & & & \\
\hline
\end{tabular}

(b) $F_{4}$

Table 2.

\begin{tabular}{|c|c|c|c|c|c|c|c|}
\hline Patir & Blor & & Whit & & Albi & ino & lotals \\
\hline & & 8 & $\bar{q}$ & 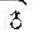 & $\%$ & 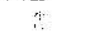 & \\
\hline $\begin{array}{l}\text { FF } 263 \text { (H.B) } \\
\text { f FF } 227 \text { (H.B) }\end{array}$ & 1 & 5 & 01 & 0 & 1 & $u$ & 7 \\
\hline$\frac{\text { FF } 263 \text { (H.B) }}{\text { GG } 64 \text { (H.B) }}$ & U & 1 & 0 & $u$ & u & 1 & 2 \\
\hline$\frac{\text { 京F } 263 \text { (H.B) }}{\text { s HH } 163 \text { (H.B) }}$ & 11 & 35 & 23 & U & 16 & 17 & $10 \%$ \\
\hline $\begin{array}{l}\text { क GG } 134 \text { (H.B) } \\
\text { o GG } 133 \text { (H.B) }\end{array}$ & 15 & 27 & 14 & 0 & 5 & 10 & 71 \\
\hline$\frac{7 \text { GG } 134(\text { H.B })}{8 \mathrm{HH} 116(\mathrm{H} . \mathrm{B})}$ & 12 & 9 & 6 & U & 4 & 8 & 39 \\
\hline $\begin{array}{l}\text { Q EE } 88 \text { (H.B) } \\
\text { FF } 192(\text { H.B) }\end{array}$ & 5 & 2 & 2 & 0 & u & 1 & 10 \\
\hline $\begin{array}{l}\text { 4 GG } 61 \text { (H.B) } \\
\text { \& GG } 62(\mathrm{H} . \mathrm{B})\end{array}$ & 20 & 40 & 25 & $\ddot{0}$ & 14 & 18 & 117 \\
\hline $\begin{array}{l}\text { PEE } 187 \text { (H.B) } \\
\text { ¿ EE } 186 \text { (H.B) }\end{array}$ & 4 & 6 & u & 0 & 4 & 2 & 16 \\
\hline$\frac{q \mathrm{EE} 183(\mathrm{H} . \mathrm{B})}{\mathrm{B}}$ & 14 & 21 & 9 & 0 & 11 & 15 & 70 \\
\hline $\begin{array}{l}\text { NN } 93 \text { (H.B) } \\
\text { EE } 182 \text { (H.B) }\end{array}$ & 3 & 3 & u & $u$ & U & u & 6 \\
\hline$\frac{\text { † EE } 248 \text { (H.B) }}{\text { f FF } 14 \text { (H.B) }}$ & 3 & 5 & 4 & $u$ & 6 & 4 & 22 \\
\hline $\begin{array}{l}\text { EE } 248(\text { H.B }) \\
\text { S GG } 141 \text { (H.B) }\end{array}$ & 16 & 26 & 11 & 0 & 10 & 8 & 71 \\
\hline $\begin{array}{l}\text { MM } 83 \text { (H.B) } \\
\text { s EE } 182 \text { (H.B) }\end{array}$ & 7 & 12 & $y$ & 0 & 1 & 1 & 30 \\
\hline $\begin{array}{l}\text { \&E 249(H.B) } \\
\text { \& GG } 8 \text { (H.B! }\end{array}$ & 18 & 39 & 15 & 0 & y & 17 & 98 \\
\hline Totals & 129 & 231 & 118 & u & 81 & 102 & 661 \\
\hline Expected & $123_{1}^{15}$ & $247_{\frac{1}{1} \frac{4}{B}}$ & $123_{10}^{15}$ & 0 & 8230 & 8213 & 661 \\
\hline Standard error & \pm 10.03 & \pm 12.45 & \pm 10.03 & & \pm 8.50 & \pm 8.50 & \\
\hline
\end{tabular}


(B) Albino o $\times$ White 3

(a) $\mathrm{F}_{\mathrm{I}}$

Table 3.

\begin{tabular}{|c|c|c|c|c|c|c|c|}
\hline Pair & \multicolumn{2}{|c|}{ Blond } & \multicolumn{2}{|c|}{ White } & \multicolumn{2}{|c|}{ Albino } & Totals \\
\hline & 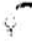 & 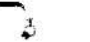 & c & is & 8 & 3 & \\
\hline$\frac{\forall \operatorname{CC} 215(\mathrm{~A})}{3 \operatorname{CC} 96(\mathrm{~W})}$ & 0 & 3 & 3 & 0 & 0 & ij & 6 \\
\hline $\begin{array}{l}* \mathrm{CC} 215(\mathrm{~A})^{* *} \\
\hat{B B B 11(\mathrm{~W})}\end{array}$ & 0 & $2 \mathfrak{G}$ & 26 & 0 & 0 & 0 & 55 \\
\hline $\begin{array}{l}\text { CC } 214(\mathrm{~A})^{* *} \\
3 \mathrm{BB} 54(\mathrm{~W})\end{array}$ & $u$ & 25 & $2 \pi$ & 0 & $u$ & 0 & 47 \\
\hline 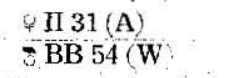 & 0 & 2 & 2 & 0 & 0 & 0 & 4 \\
\hline Totals & u & 59 & 53 & u & 0 & u & 112 \\
\hline Expected & 0 & 56.0 & 56.0 & 0 & 0 & 0 & 112 \\
\hline Standard error & & \pm 5.29 & $\llcorner 5.29$ & & & & \\
\hline
\end{tabular}

(b) $\mathrm{F}$ :

Table 4

\begin{tabular}{|c|c|c|c|c|c|c|c|}
\hline \multirow[t]{2}{*}{ Pair } & \multicolumn{2}{|c|}{ Blond } & \multicolumn{2}{|c|}{ White } & \multicolumn{2}{|c|}{ Albino } & \multirow[t]{2}{*}{ Totals } \\
\hline & צ̧ & 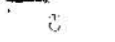 & $\div$ & 3 & 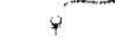 & 3 & \\
\hline $\begin{array}{l}\text { FF } 269(\mathrm{H} . \mathrm{W}) \\
3 \mathrm{FF} 67(\overline{\mathrm{H}} \cdot \mathrm{B})\end{array}$ & 14 & $2 i$ & 23 & 21 & 9 & 12 & 100 \\
\hline $\begin{array}{l}\text { \&F } 148(\mathrm{H} . \mathrm{W}) \\
\text { \&FF } 147(\mathrm{H} . \overline{\mathrm{B}})\end{array}$ & 33 & 21 & 30 & 21 & 13 & 27 & 145 \\
\hline$\frac{\partial \mathrm{FF} 68(\mathrm{H} . \mathrm{W})}{\frac{\mathrm{EE}}{139(\mathrm{H}: \mathrm{B})}}$ & 13 & 14 & 15 & 20 & ૪ & $\ddot{b}$ & 76 \\
\hline $\begin{array}{l}\frac{q \mathrm{HH}}{22}(\mathrm{H} . \mathrm{W}) \\
\$ \mathrm{EE} 139(\mathrm{H} . \mathrm{B}) \\
\cong \mathrm{FF} 1(\mathrm{H} . \mathrm{W})\end{array}$ & 13 & $1 \%$ & 10 & 11 & 8 & 12 & 66 \\
\hline O EE 57 (H.B) & 22 & 11 & 11 & 17 & 19 & 16 & 96 \\
\hline$\frac{q \mathrm{FF} 66(\mathrm{H} . \mathrm{W})}{\mathrm{EEE} 194(\mathrm{H} \cdot \mathrm{B})}$ & 8 & $\mathrm{~s}$ & 6 & 8 & 11 & 8 & 46 \\
\hline$\frac{\text { FF } 66(\text { H.W })}{\delta H H 100(\text { H.B })}$ & 19 & 8 & 17 & 12 & 11 & 7 & 74 \\
\hline$\frac{2 \mathrm{HH} 161 \text { (H.W) }}{3 \mathrm{FF} 195 \text { (H.B) }}$ & 14 & 18 & 17 & 17 & 16 & 8 & 90 \\
\hline$\frac{\frac{\alpha H}{H} 142(\mathrm{H} . W)}{\partial \overline{\mathrm{FF}} 195(\mathrm{H} . \overline{\mathrm{B}})}$ & 6 & 6 & 5 & 3 & 3 & 2 & 25 \\
\hline Totals & 142 & 116 & 134 & 130 & 98 & 98 & 718 \\
\hline Expected & $134 \frac{120}{10}$ & $134 \frac{1}{1} \frac{0}{6}$ & $134 \frac{1}{10}$ & $134_{10}^{30}$ & $891 \frac{2}{16}$ & $89 \frac{12}{16}$ & 718 \\
\hline Standard error & $\therefore 10.46$ & \pm 10.46 & \pm 10.46 & $\perp 10.46$ & \pm 8.86 & $=8.86$ & \\
\hline
\end{tabular}

* The same pair and number of offspring as described in the previous paper.

${ }^{*}$ The same pair as described in the previous paper, but the number of offspring increased. 


\section{(C) Miscellaneous Crossing}

(a) $F_{1}$ white of of Section B.a. $\times$ "Albino I"

Table 5.

\begin{tabular}{|c|c|c|c|c|c|c|c|}
\hline \multirow[t]{2}{*}{ Pair } & \multicolumn{2}{|c|}{ Blond } & \multicolumn{2}{|c|}{ White } & \multicolumn{2}{|c|}{ Albinu } & \multirow[t]{2}{*}{ Totals } \\
\hline & Q & 3 & 9 & f & 8 & $\hat{\imath}$ & \\
\hline$\frac{\forall \text { FF } 272(\mathrm{H} . W)}{\delta \text { FF } 197(\mathrm{~A})}$ & 4 & 5 & 0 & 0 & 10 & 5 & 24 \\
\hline $\begin{array}{l}\text { ₹ FF 191(H.W) } \\
\text { S EE 230(A) }\end{array}$ & 30 & 31 & 0 & 0 & 30 & 24 & 115 \\
\hline Totals & 34 . & 36 & 0 & 0 & 40 & 29 & 139 \\
\hline Expected & 34 & $34 \frac{4}{4}$ & 0 & 0 & $34 \frac{4}{4}$ & $34 \frac{3}{4}$ & 139 \\
\hline Standard error & +5.11 & \pm 5.11 & & & & \pm 5.11 & \pm 5.11 \\
\hline
\end{tabular}

(b) "Albino I" $\% \times F_{1}$ blond $\delta$ of Section B.a.

Table 6 .

\begin{tabular}{|c|c|c|c|c|c|c|c|}
\hline Pair & \multicolumn{2}{|c|}{ Blond } & \multicolumn{2}{|c|}{ White } & \multicolumn{2}{|c|}{ Albino } & Totais \\
\hline & 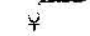 & $\hat{\alpha}$ & $\$$ & & $\zeta^{\top}$ & $x$ & \\
\hline 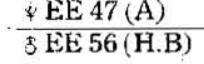 & 5 & l'i & 6 & 0 & 12 & 10 & 50 \\
\hline Expected & $6_{8}^{2}$ & $122_{B}^{4}$ & $6 \frac{2}{8}$ & 0 & $12:$ & $12 z$ & 50 \\
\hline Standard error & \pm 2.34 & \pm 3.06 & \pm 2.34 & & \pm 3.06 & \pm 3.06 & \\
\hline
\end{tabular}

(c) $\mathrm{F}_{2}$ albino $\& \times$ White 8.

(i) $F_{2}$ albino $q$ of Section A.b. $\times$ White $s$.

Table 7

\begin{tabular}{|c|c|c|c|c|c|c|c|}
\hline Pair & & & Wh & & & & Totals \\
\hline & 4 & 3 & क & d & Y & a & \\
\hline$\frac{\psi \mathrm{HH} 36(\mathrm{~A})}{3 \mathrm{CC} 184(\mathrm{~W})}$ & 0 & 2 & 2 & 0 & 0 & 0 & 4 \\
\hline$\frac{2 \mathrm{HH} 36(\mathrm{~A})}{5 \mathrm{BB} 54(\mathrm{~W})}$ & 0 & 2 & 2 & $u$ & 0 & 0 & 4 \\
\hline$\frac{2 \mathrm{GG} 4(\mathrm{~A})}{\text { 5 DD } 198(\mathrm{~W})}$ & 0 & 51 & 57 & 0 & $u$ & $u$ & 108 \\
\hline Totals & 0 & 55 & 61 & 0 & 0 & 0 & 116 \\
\hline Expected & 0 & 58.0 & 58.0 & 0 & 0 & 0 & 116 \\
\hline Standard error & & \pm 5.39 & \pm 5.39 & & & & \\
\hline
\end{tabular}


(ii) $\mathrm{F}_{2}$ albino $q$ of Section B.b. $\times$ White $\delta$.

Table 8.

\begin{tabular}{|c|c|c|c|c|c|c|c|}
\hline Pair & \multicolumn{2}{|c|}{ Blond } & \multicolumn{2}{|c|}{ White } & \multicolumn{2}{|c|}{ Albino } & Totals \\
\hline & $\dddot{7}$ & $\hat{o}$ & $q$ & 8 & $\%$ & 0 & \\
\hline$\frac{\$ \mathrm{GG} 37(\mathrm{~A})}{\text { \&DD } 198(\mathrm{~W})}$ & 0 & 0 & 4 & 2 & 0 & 0 & 6 \\
\hline$\frac{9 \text { HH } 37(\mathrm{~A})}{\hat{\alpha} \mathrm{CC} 184(\mathrm{~W})}$ & $\mathrm{o}$ & 0 & 5 & 7 & 0 & 0 & 12 \\
\hline$\frac{8 \mathrm{HH} 72(\mathrm{~A})}{\mathrm{B} \mathrm{CC} 184(\mathrm{~W})}$ & 0 & 0 & 1 & 1 & 0 & 0 & 2 \\
\hline Totals & 0 & 0 & 10 & 10 & 0 & 0 & 20 \\
\hline Expected & 0 & 0 & 10.0 & 10.0 & 0 & 0 & 20 \\
\hline
\end{tabular}

(d) White $q \times \mathrm{F}_{2}$ albino $\delta$ of Section B.b.

Table 9 .

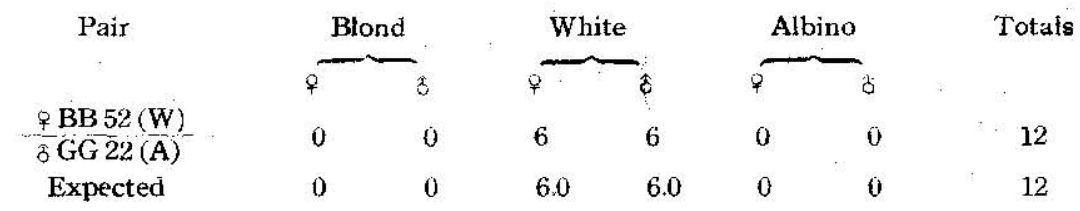

(e) "Albino II" 우 $\times$ White

Table 10.

\begin{tabular}{|c|c|c|c|c|c|c|}
\hline Pair & Blond & & & & & Totals \\
\hline & के & 立 & 8 & & 3 & \\
\hline$\frac{q \mathrm{KK}}{8 \mathrm{BB}} 2 \frac{2 \mathrm{~A}(\mathrm{~A})}{\mathrm{W})}$ & $v$ & 8 & 8 & 0 & 0 & 16 \\
\hline Expected & 0 & 8.0 & 8.0 & 0 & 0 & 16 \\
\hline
\end{tabular}

(f) "Albino II"..$\times \times$ Parent of albino mutants.

Table 11.

\begin{tabular}{|c|c|c|c|c|c|c|c|}
\hline \multirow[t]{2}{*}{ Pair } & \multicolumn{2}{|c|}{ Blond } & \multicolumn{2}{|c|}{ White } & \multicolumn{2}{|c|}{ Albino } & \multirow{2}{*}{ Totals } \\
\hline & q & $\delta$ & 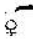 & 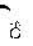 & O+ & $\delta$ & \\
\hline$\frac{9 \mathrm{JJ} 5(\mathrm{~A})}{\mathrm{BB} 6 \mathrm{~B}(\mathrm{~B})}$ & 8 & 11 & 0 & 0 & 13 & 8 & 40 \\
\hline
\end{tabular}




$\begin{array}{lccccccc}\frac{9 \mathrm{JJ} 92(\mathrm{~A})}{\mathrm{S} \mathrm{BB} 10(\mathrm{~B})} & 11 & 18 & 0 & 0 & 9 & 15 & 53 \\ \text { Totals } & 19 & 29 & 0 & 0 & 22 & 23 & 93 \\ \text { Expected } & 23 \frac{1}{4} & 23 \frac{1}{4} & 0 & 0 & 23 \frac{1}{4} & 237 & 93 \\ \text { Standard error } & \pm 4.18 & \pm 4.18 & & & \pm 4.18 & \pm 4.18 & \end{array}$

(g) $F_{1}$ white $q$ of Section B.a. $\times$ Albino $\delta$ of Section C.b.

Table 12 .

\begin{tabular}{|c|c|c|c|c|c|c|c|}
\hline \multirow[t]{2}{*}{ Pair } & \multicolumn{2}{|c|}{ Blond } & \multicolumn{2}{|c|}{ White } & \multicolumn{2}{|c|}{ Albino } & Totals \\
\hline & क & 8 & \% & 3 & क & $\hat{\imath}$ & \\
\hline$\frac{\text { ㅇF } 271(\mathrm{~W})}{3 \text { FF } 193(\mathrm{~A})}$ & 8 & 5 & 9 & 6 & 13 & 20 & 61 \\
\hline Expected & $7 \frac{5}{5}$ & $7 \frac{5}{8}$ & 7 珤 & $7 \frac{5}{8}$ & $15 z$ & $15 z$ & 61 \\
\hline Standard error & \pm 2.58 & \pm 2.58 & \pm 2.58 & \pm 2.58 & \pm 3.38 & \pm 3.38 & \\
\hline
\end{tabular}

(D) Pure Breeding of "Albino II"

Table 13.

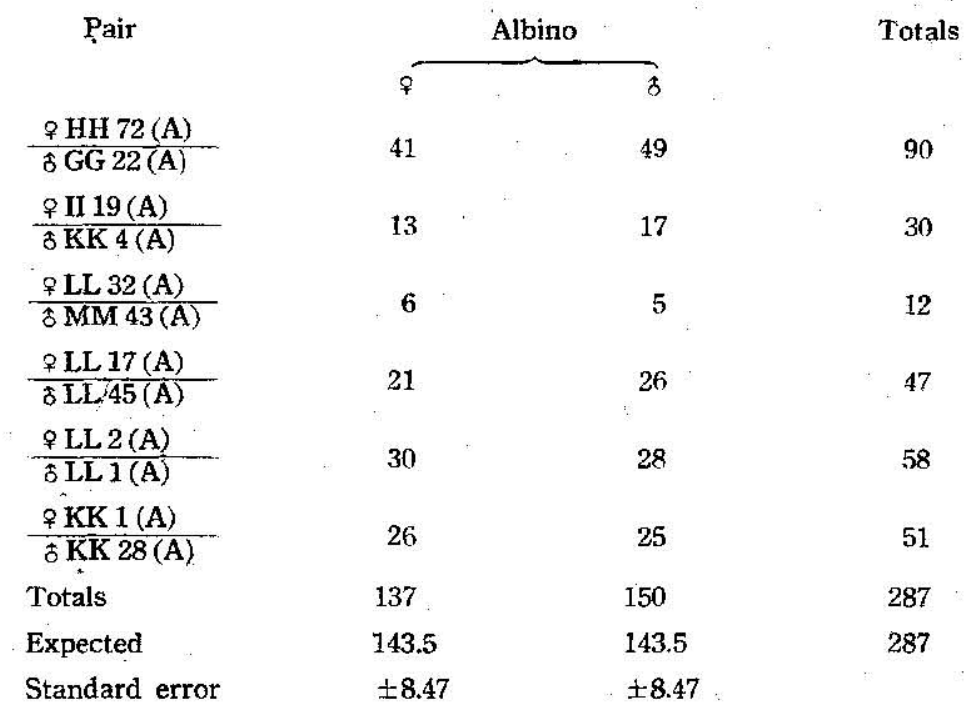


(E) To Distinguish "Albino II" from "Albino I"

(i) To distinguish "Albino II" ㅇ from "Albino I"

Table 14,

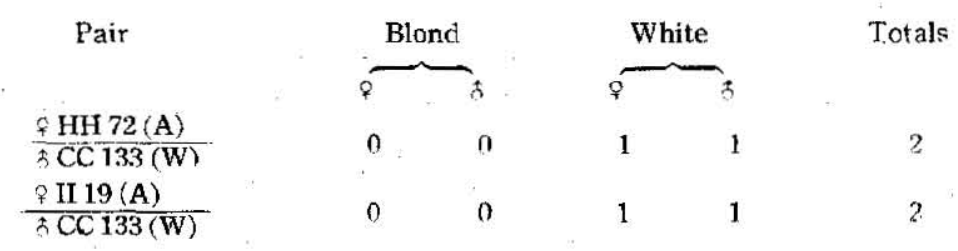

Each of the birds $\% \mathrm{HH} 72(\mathrm{~A})$ and $\mathrm{II} 19(\mathrm{~A})$ produced a white male offspring from the crossing with white male, and this enables us to regard the birds as "Albino II".

(ii) To distinguish "Albino II" of from the Albino of which is heterozygous with respect to the gene $I$.

Table 15.

\begin{tabular}{|c|c|c|c|c|c|}
\hline Pair & \multicolumn{2}{|c|}{ Blond } & \multicolumn{2}{|c|}{ White } & Totals \\
\hline & & $\hat{3}$ & ? & $\theta$ & \\
\hline 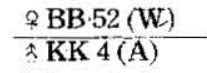 & 0 & 0 & 5 & 5 & 10 \\
\hline Expected & 0 & 0 & 5.0 & 5.0 & 10 \\
\hline Standard error & & & \pm 1.58 & +1.58 & \\
\hline
\end{tabular}

The results obtained from the crossing metioned above are enough to discriminate the bird $3 \mathrm{KK} 4$ (A) to be the "Albino II" 3 , for the reason described in Section 3. a. ii. under Consideration (p. 140).

\section{CONSIDERATION}

(1) $F_{1}$ and $F_{2}$. The experimental results of crossing albino ring doves ("Albino I") with white ones were described in the previous paper, and assumptions were made: the blond color of plumage in the ring dove was due to two factors which were named by the writer "C" and "I", $C$ being an autosomal color factor and responsible for developing the plumage color and eye 
color characteristic to the white ring dove, $I$ being a sex-linked intensity factor unable to exhibit any coloration by itself and causing the bird to remain an albino. The genetic formulae for the white and albino ring doves were designated as follows:

White ring doves: $=\mathrm{CCZ} W, \quad \hat{s}=\mathrm{CCZZ}^{\mathrm{i}}$;

Albino ring doves: $\quad==c c Z^{\top} W, \quad \hat{\mathrm{W}}=\mathrm{ccZ} Z^{\top}$.

The results shown in Tables $1,2,3$ and 4 may be interpreted by the following scheme of inheritance:

(A)

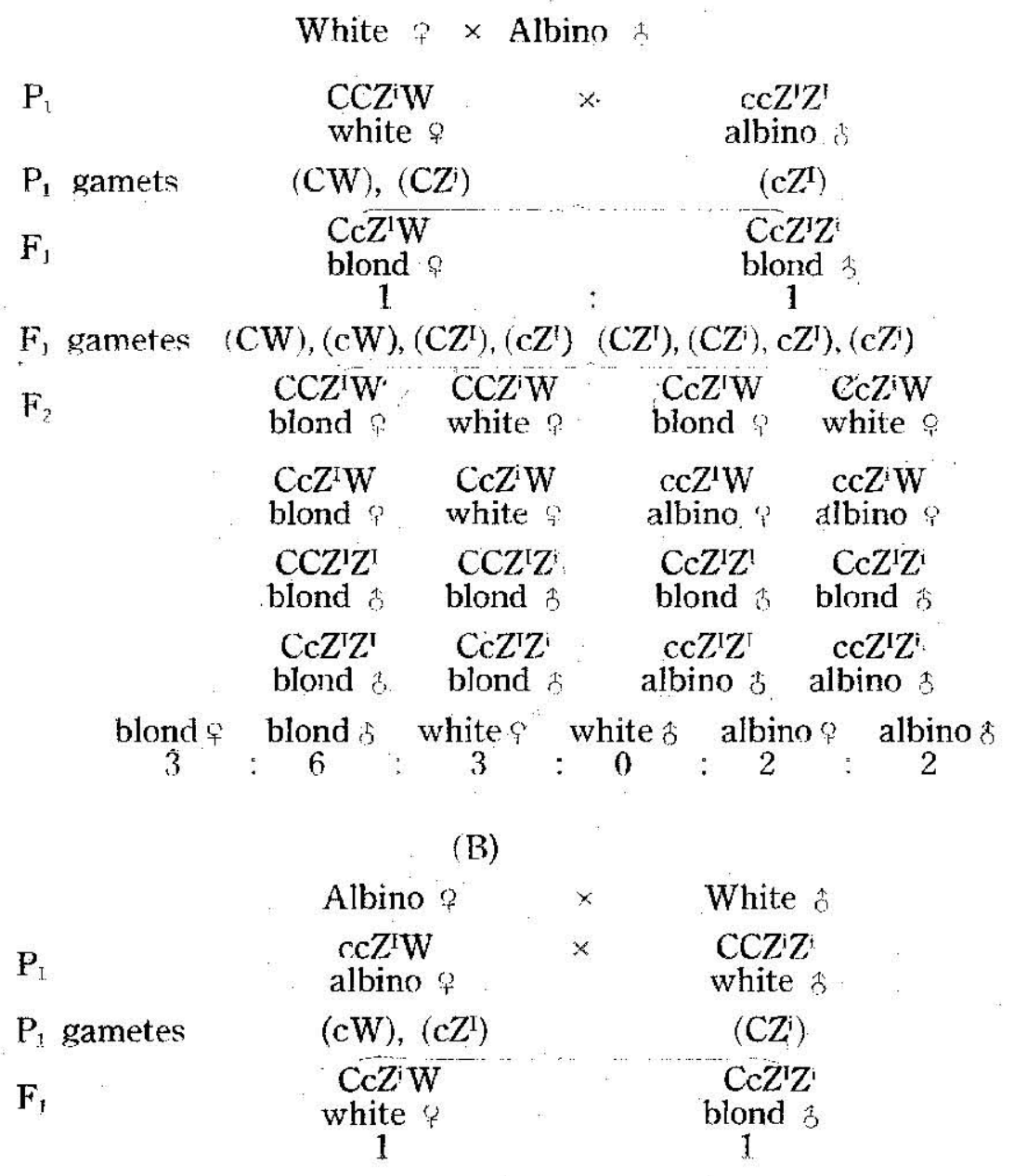




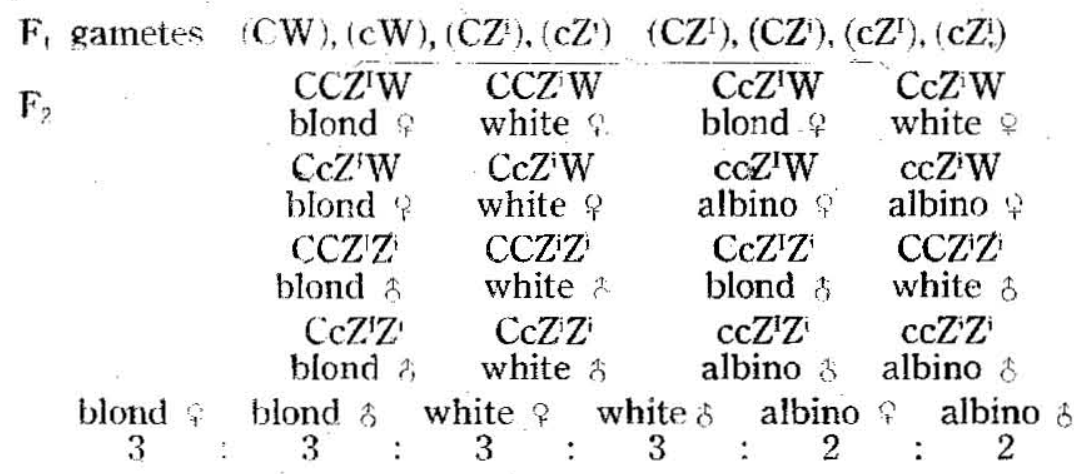

As is shown in Tables $1,2,3$ and 4 , the actual numbers of offspring, i.e., $F_{1}$ and $F_{2} e x$ White $q \times$ Albino $s$ as well as those ex Albino $\& \times$ White $A$, are not far from the theoretical ones calculated upon the above scheme; deviations do not exceed three times the standard errors.

(2) Various Cases of Crossing. The results described in Tables 5, 6, 7, 8, 9, 10, 11 and 12 are obtained from the miscellaneous crossing, and may be interpreted by the same scheme as described above. Thus:

(a) F, white $?$ of Section B.a. $\times$ "Albino I" $\hat{b}$. (Table 5).

The $\mathbf{F}_{1}$ white is heterozygous with respect to the gene $C$, and produces four kinds of gametes instead of two (Cf. $\mathrm{P}_{1}$ of Section A). Consequently there occurs both blond and albino offspring in $F_{1}$ when it is mated with "Albino $I$ " $B$; it differs from $\mathrm{F}_{1}$ ex pure White $\mathrm{R} \times$ “Albino $\mathrm{I}$ ” 8 :

\begin{tabular}{|c|c|c|}
\hline $\begin{array}{l}P_{1} \\
P_{1} \text { gametes }\end{array}$ & $\begin{array}{l}\mathrm{CcZ}^{\mathrm{i} W} \\
(\stackrel{\mathrm{CW}}{ }),(\mathrm{CZ}),(\mathrm{cW}),\left(\mathrm{cZ} Z^{\mathrm{i}}\right)\end{array}$ & $\begin{array}{c}c c Z^{I} Z^{I} \\
c Z^{i}\end{array}$ \\
\hline$F$ & $\begin{array}{cc}\mathrm{CcZ}^{\prime} W & \mathrm{CcZ}^{\prime} \mathrm{z} \\
\text { blond } & \text { blond } \beta\end{array}$ & $\begin{array}{l}\mathrm{ccZ}^{\mathrm{I} W} \\
\text { albino }\end{array}$ \\
\hline
\end{tabular}

The experimental results shown in Tablc 5 are in agreement with the theoretical expectation.

(b) "Albino I" $? \times \mathrm{F}_{1}$ blond 3 of Section B.a. (Table 6).

The $\mathrm{F}_{f}$ blond $\hat{s}$ is heterozygous with respect to genes $C$ and 
$I$, and generates four kinds of gametes. When it is crossed with all "Albino I" 9 all appear blond, white and albino offspring, except white 1 .

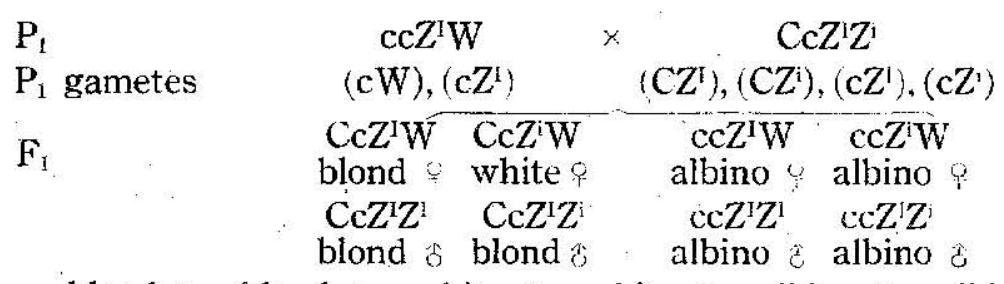

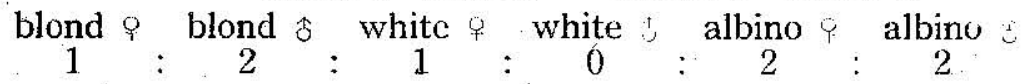

The results shown in Table 6 agree with the theoretical expectation, although the actual numbers of progeny are not large.

(c) $\mathrm{F}_{2}$ albino $q \times$ White 8 . (Tables 7 and 8 ).

There are two kinds of $\mathrm{F}_{2}$ albino $q$ ex both White $\% \times$ Albino $s$ and Albine $o \times$ White $s$, and they are to be designated genetically as ccZi $\mathrm{W}$ and ${ }^{\mathrm{c}} \mathrm{Z}^{\mathrm{i}} \mathrm{W}$ as shown in the scheme described above. When they are crossed with White 3 , the former produces $F_{i}$ 's of blond $s$ and white $s$ in equal number, while the latter produces $F_{1}$ 's of white $f$ and white $\hat{s}$ in equal number, no blond offspring at all in this case; for example, HH 36 shown in Table 7 is an $F_{2}$ albino $\%$ of Section A. b. and GG 37 is an $F_{2}$ albino $?$ of Section B.b., the former is to be designated as $c c Z^{1} W$ and the latter as $c c Z^{2} \mathrm{~W}_{2}$ : there are $\mathrm{F}_{2}$ albino o's which are to be designated as $c c Z$ W in Section $A$. b., and there are also $F_{2}$ albino $P$ 's which are to be designated as $c c Z^{\top} \mathrm{W}$ in section B.b. The scheme of inheritance is as follows:

(i) $\mathrm{P}_{1}$

$P_{1}$ gametes

$F_{1}$

(ii) $P_{3}$,gametes

$\mathrm{P}_{\mathrm{i}}$ gametes

$\mathrm{F}_{1}$

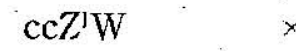

$\left(\mathrm{cZ}^{\mathrm{I}}\right),(\mathrm{cW})$

$\mathrm{CcZ} Z^{\mathrm{i}}$

blond $s$

1

${ }^{\mathrm{cc}} \mathrm{WW}$

(cW), (cZi)

$\mathrm{CeZ} \mathrm{W}$

white

1
$\mathrm{CCZ}^{1}$

$\left(\mathrm{CZ}^{2}\right)$

$\mathrm{CcZ} W$

white

1

ICZZ

$\mathrm{CcZ} Z^{\mathrm{i}}$

white $\mathrm{s}$ 
All the results of crossing -are in agreement with the theoretical expectation although the number of individuals is small.

The albino females lacking in $I$ are the "Albino II" females named so by the writer.

(d) White $q \times \mathrm{F}_{2}$ albino 2 of Şection B.b. (Table 9).

There are two kinds of $\mathrm{F}_{2}$ albino $s$ of Section B.b., i.e., $c c Z^{\mathrm{I} Z}$ and $c c Z$ Zi . When they are crossed with white $q$, the former produces both blond and white offspring, while the latter produces white offspring only; $F_{2}$ albino such as GG22 in Table 9 must be an individual of the genetic constitution of $\mathrm{ccZ}^{\mathrm{Z}} \mathrm{i}$. The results If crossing white $\$$ with $\mathrm{F}_{2}$ albino $\delta$ of the genetic constitution If $\mathrm{ccZ}^{\mathrm{I}} \mathrm{Z}^{\circ}$ have not been obtained in the present crossing experinents.

(i) $\mathrm{P}_{1}$

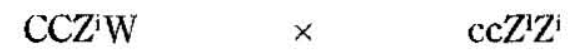

$$
P_{i} \text { gametes } \quad(\mathrm{CW}),\left(\mathrm{CZ}^{\mathrm{i}}\right) \quad\left(\mathrm{cZ}^{\mathrm{I}}\right)(\mathrm{cZ})
$$

$\mathrm{F}_{1}$

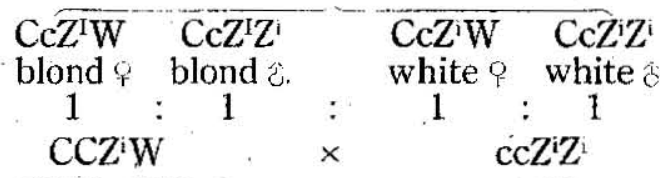

(ii) $\mathrm{P}_{1}$

(CW), (CZi) (cZi)

$P_{1}$ gametes

$\mathrm{CcZiW}$

white?

1

\section{$\mathrm{CcZZ}^{2}$}

white 8

The results of crossing shown in Table 9 correspond to the scheme described in (ii) above; and the bird GG22 is to be regarded as an "Albino II" $\delta$.

(e) “Albino II" $\times$ White 1 . (Table 10).

As the albino $\mathrm{KK} 22$ shown in Table 10 is the female offspring ex $\mathrm{HH} 72$ (A) in Table $8 \times \mathrm{GG} 22$ (A) in Table 9 , the former being of the genetic constitution of ${ }^{c} Z^{i W}$ and the latter of $c c Z^{i}$ (Cf. the preceding Section), it belongs only to "Albino II", and the crossing of the present Section is identical with that of Section c. ii.
$P_{1}$
ccZiW
$\times$
$\mathrm{CCZZ}^{\mathrm{Z}}$
$P_{1}$ gametes
(cW), (cZi) 


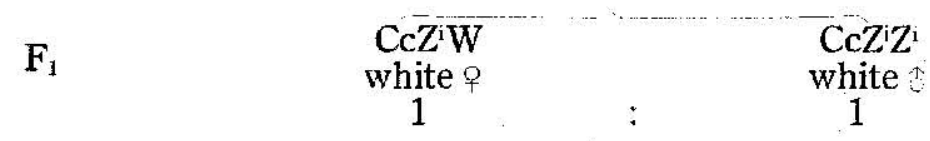

(f) "Albino II" $q \times$ Parent of albino mutants. (Table 11).

As the male parent of albino mutants may be designated as CcZl' (Tange, 1934), the results of crossing "Albino II" o with the male parent are able to be explained by the following scheme of inheritance:

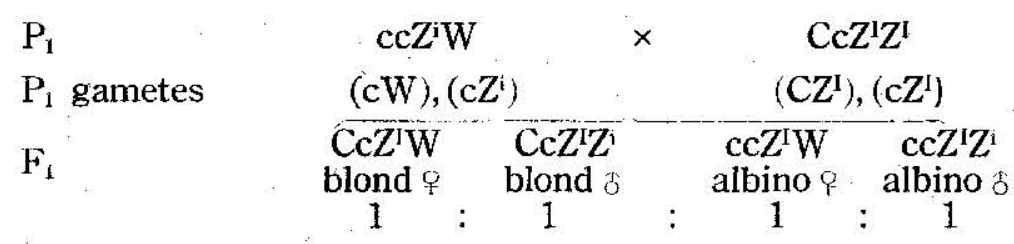

The results of crossing are in approximate agreement with the theoretical expectation as shown in Table 11.

(g) F, white of of Section B.a. $\times$ Albino ô of Section C.b. (Table 12).

The genetic constitution of the $F_{1}$ white $Q$ of Section B.a. is $\mathrm{CcZ}^{\mathrm{i} W}$ as shown above. There are two kinds of genetic constitution of albino $s$ of Section C. b., viz., ccZIZ $Z^{1}$ and $\operatorname{ccZ}^{1} Z$, the former belonging to "Albino I". The male bird FF193(A) in Table 12 is considered to be designated as $c c Z^{1} Z^{i}$ instead of ${ }^{2} Z^{1} Z^{1}$, because there occurred white offspring when it was crossed with female white bird, (Cf. Section C.a.). Thus:

\begin{tabular}{|c|c|c|c|c|}
\hline $\begin{array}{l}P_{1} \\
P_{1} \text { gametes }\end{array}$ & $\begin{array}{r}\mathrm{Cc} \\
(\mathrm{CW}),(\end{array}$ & $\begin{array}{l}\mathrm{W} \\
\mathrm{V}),(\mathrm{CZ}),(\mathrm{cZ})\end{array}$ & & $\begin{array}{l}\mathrm{cZ}^{\mathrm{I}} \mathrm{Z}^{\mathrm{i}} \\
)^{\prime}\left(\mathrm{c}^{\mathrm{i}}\right)\end{array}$ \\
\hline$F_{1}$ & $\begin{array}{l}\text { CcZi } \mathrm{W} \\
\text { blond ? }\end{array}$ & $\begin{array}{l}\mathrm{Cc} Z \mathrm{~W} \\
\text { white? }\end{array}$ & $\begin{array}{r}\operatorname{cc} Z^{\prime} W \\
\text { albino? }\end{array}$ & $\begin{array}{l}\text { ccZi W }^{i}{ }^{2} \text { albino } f\end{array}$ \\
\hline & $\begin{array}{l}\mathrm{CcZ} Z \\
\text { blond }\end{array}$ & $\begin{array}{c}\text { CcZiZi } \\
\text { white dै }\end{array}$ & $\begin{array}{c}\operatorname{ccZ} Z^{1} \\
\text { albino } 3\end{array}$ & $\begin{array}{l}\operatorname{ccZ} Z^{i} \\
\text { albino } 8\end{array}$ \\
\hline
\end{tabular}

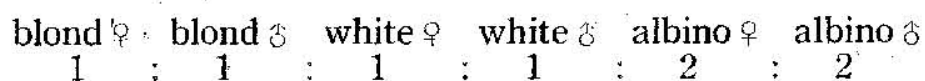

The results of crossing shown in Table 12 are well explained 
by the scheme mentioned above, the actual numbers secured being not far from the theoretical ones; the deviations do not exceed three times the standard errors.

(3) The "Albino II" Individuals Breed True.

(a) To distinguish genotypically the "Albino II" from the "Albino I" by the progeny test. (i) To distinguish genotypically the "Albino II" from the "Albino I" o. This is simple since the "Albino I" " produces male offspring of blond plumage color when it is crossed with White $\delta$, while the "Albino II" $\psi$ does not produce such colored offspring when crossed with White (Cf. Sections c.i., c.ii. and e.). The female birds HH72 (A) and II 19 (A) shown in Table 14 can be considered as individuals belonging to "Albino II", because both of them produced male offspring of white plumage color. (ii) To distinguish genotypically the "Albino II" as from the Albino $\hat{o}$ which is heterozygous with respect to the gene I, i.e., Albino 13 designated as $c c Z Z$. The "Albino I" produces blond offspring only in $\mathrm{F}_{1}$ when it is crossed with the white female as was shown in Table 1 , while the "Albino II" is produces white offspring only in $F_{1}$ when it is crossed with the white female as was explained in Section d. ii. Thus the "Albino II" o may be distinguished from the "Albino I". without difficulty by the progeny test. We will consider next the method of distinguishing the "Albino II" $\hat{\delta}$ from the Albino 0 heterozygous with respect to the gene 1 . The Albino designated as ccZ' $Z^{\mathrm{i}}$ produces both blond and white offspring in equal number as was shown in the scheme of inheritance described in Section d.i., while the "Albino II" o produces white offspring only when crossed with the white female. So if the total number of offspring produced by an albino $s$ crossed with a white $\phi$ is at least 10 and all are white without exception, this enables us to determine the albino $\delta$ to be an "Albino II" $\delta$ and never to be an Albino of $c \subset Z^{l} Z^{j}$; thus the deviation and standard error of experiments calculated on the assumption that the ratio of the blond birds to the white ones which will be produced by crossing Albino $s$ of $\operatorname{ccZ}^{\prime} Z^{i}$ with white of $\mathrm{CCZ}^{\mathrm{W} W}$ is $1: 1$, are \pm 5.0 and \pm 1.58 , respectively; the deviation exceeds three times the standard error, 
so the experimental results, which secure 10 birds of white plumage without exception, are not expTainable by the scheme of $\mathrm{CCZ}^{\mathrm{W}} \mathrm{W} \times \mathrm{ccZ} Z$ (Cf. Sections d. i. and d. ii.).

(b) The "Albino II" individuals breed true. An $\mathrm{F}_{2}$ albino female HH72 was mated with an $\mathrm{F}_{2}$ albino male GG22 as shown in Table 13, both of them being the progeny ex Albino of $\times$ White $\delta$ of Section $B$, and having been shown, as mentioned above, that they are of the genetic constitution ${ }^{2} Z^{i} W$ and $c c Z Z^{i}$, respectively. They have bred 90 individuals up to the present, all albino, 41 being females and 49 males. The other five pairs shown in Table 13 are all the offspring ex HH72 $\times$ GG22. Two individuals o II 19 as well as $1 \mathrm{KK} 4$ out of 10 have shown that they have no.I gene in their genetic constitution as a result of crossing them with white birds as shown in Tables 14 and 15; the remaining eight individuals are sure to be of the same genetic constitution as the two. Thus a new kind of albino ring doves of the genetic constitution $\rho=c c Z W$ and $s=c c Z Z$ have been bred, and they breed true.

\section{SUMMARY AND CONCLUSION}

(1) Further data on the crossing of albino ring doves with white ones are presented in this paper.

(2) It is shown that the results of crossing experiments presented in this paper are all satisfactorily explained by the twofactor hypothesis brought forward by the writer (Tange, 1934). The blond color of plumage in the ring dove is developed by the combination of two factors: one being that which is responsible for the white plumage color and the dark eye color characteristic of the white ring dove, and the other being the intensity factor. The intensity factor can not develop coloration by itself, therefore it leaves the bird an albino with the snow-white plumage and the red eye. The two factors are the color factor $C$ and the intensity factor $l$, the former being autosomal and the latter sex-linked as described in a paper published in 1934.

(3) Albino ring doves lacking both $C$ and $I$ factors and desi-

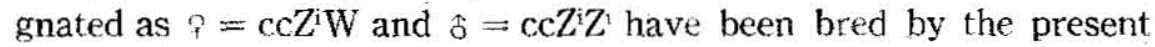
crossing experiments. They breed true and have established 
another kind of albino ring doves which the writer named "Albino II"

\author{
Laboratory of Zootechny, Faculty of Agnculture,
} Kyushu University. July, 1948.

\title{
BIBLIOGRAFHY
}

1. Tange, M. 1932. Unexpected occurrence of albino individuals in the offspring of blond ring doves, Streptopelia risoria. (In Japanese with an English résumé). Japanese Jòur. Genetics, 8. Pp. 1-18.

2. 1934. Studies on the sex-linked inheritance of plumage color in the ring dove, Streptopelia risoria., Jour. Dept. Agric., Kyushu Imp. Univ., 4. Pp. 161-194. 